\title{
Alter-Egos: Cultural and Media Studies
}

Keyan G. Tomaselli

Director: The Centre for Communication, Media and Society (CCMS)

The University of KwaZulu-Natal

tomasell@ukzn.ac.za

$+27312602635$

http://ccms.ukzn.ac.za

Mailing Address:

The Centre for Communication, Media and Society (CCMS)

Room G006A, MTB, Ground Floor

UKZN, Howard College

Masizi Kunene Avenue

Durban, 4041

Keyan G. Tomaselli is Director of The Centre for Communication, Media and Society, University of KwaZulu-Natal. He is a Fellow of the University and of the International Communicology Institute, and served on a Consensus Panel: Humanities and Social Science of the Academy of Science of South Africa (2009-11). tomasell@ukzn.ac.za

\begin{abstract}
A periodised case study is offered of a number of engagements undertaken by The Centre for Communication, Media and Society, University of KwaZulu-Natal, Durban, between 1985 and 2012 in facilitating resistance, policy, development and analysis. How cultural and media studies travelled to South Africa and how the Centre negotiated the intersections between the Humanities and Social Sciences, Health and the Physical Sciences, is examined in terms of the epistemological alliances and conflicts that emerged. New paradigms ranging from appropriations of African philosophy and critical indigenous methodologies are discussed in an environment where new nationalisms are emerging. The story of the Centre offers the fulcrum around which to discuss specific paradigmatic shifts. A new imaginary for the Humanities and Social Sciences for a rapidly changing South Africa is then briefly proposed.
\end{abstract}

Keywords: cultural and media studies, humanities, indigenisation, paradigm shift, social sciences, South Africa, travelling theory.

\section{Acknowledgements:}

My thanks to the Academy of Science of South Africa Consensus Panel for the opportunity of researching issues on the future of the Humanities and Social Sciences, notably co-chairs Peter Vale and Jonathan Jansen. My thanks to Sarah Strauss for editing the many drafts of this paper, as well as her administrative support. 


\section{Alter-Egos: Cultural and Media Studies}

\section{Early South African Cultural and Media Studies}

From the mid-twentieth century, Media Studies and its alter-ego, Cultural Studies, examined media-society and power relations within modernity in understanding relationships between resistance and domination.

The field was introduced to South Africa in a recontextualised form in the late-1970s. Initially, early forms of a still emergent Cultural and Media Studies (CMS) entered English South African scholarship via the History Workshop at the University of Witwatersrand and Development Studies, specifically in the form of discussions on, and critiques of, Louis Althusser (1971a;1971b), Antonio Gramsci (1971) and other historical materialists. An early formal site was Critical Arts (1980ff) which adopted and adapted these theorists and theories to a critical counter-Arnoldian discussion of arts, film, media and drama (see Tomaselli and Shepperson 2000b; Visser 1984). International delegates like Susan Gardner, a literary scholar, exposed Critical Arts editors to the work of the Birmingham Centre for Contemporary Cultural Studies (CCCS), though E.P. Thompson's culturalism was the Workshop's preferred genre ${ }^{1}$.

Like Stuart Hall (1980) and Richard Johnson's (1979) reflexive examinations of their own Centre in Birmingham, I offer a historical and hopefully self-reflective analysis of the role that The Centre for Communication, Media and Society (CCMS) has played in the South African context as is constructed from within the Centre itself. A compelling self-reflection on the early Birmingham experience (Grossberg 2010; see also Webster 2004) adds a contingent dimension, as we all approached the same project from the perspectives of our different positions and subjectivities. Overlaid on this are African approaches, where, like my own early work on

\footnotetext{
${ }^{1}$ For debates on CS epistemology see Louw (1992a) and Kronenberg (2009). Caldwell (2009; see also Hall 2009) excavated a pre-Hall moment of Taylorism as a progenitor of the field. Hall (1997) discussed identity and the popular in summarising a Durban seminar (Teer-Tomaselli and Roome 1997).
} 
popular performance, Handel Wright (1998, 2003) argues for a specific indigenised appreciation. $^{2}$

The Durban Centre, established in January 1985, included a social justice approach by working alongside, with and through civil society and faith-based organisations. After 1990, the Centre moved into a number of general trajectories: CMS, policy, development and public health an development communication. Action research and critical indigenous methodological applications offered praxis-orientated solutions for a newly democratising society. Indigenisation of theory and methods, the study of African philosophers, and the social usefulness of its work were paramount.

UKZN was the first to systematically introduce CMS to South Africa, though elements of the approach had been earlier independently identified by Les Switzer (1980) and Belinda Bozzoli (1981). The UKZN project arose out of the 1976 Soweto uprising when a group of students and academics coalesced around the question: "why had resistance in South Africa failed in comparison to elsewhere?' They had wanted to establish something like the transdisciplinary CCCS that was theorising the relationship between domination and resistance. Then, in early 1984, new upper management at Natal University (NU) swept aside conservative institutional influences and CCMS was established in January 1985.

Our work was nevertheless contested by many within the University: the Left because the Centre interpreted British, Soviet and South American media theories and materialist semiotic methods into the local environment when an exclusive bottom-up indigenised workerist labour position was preferred, a trajectory that characterised the Wits History Workshop. Liberals were concerned with CMS's Marxist-leaning tendencies, but accepting of the academic 'standards' achieved. Others queried the study of 'media' and 'culture' in any guise. This was a period when these two sites were dirty words in the English South African academic lexicon, so effectively had the government recruited them for the apartheid project. The idea of media and culture being

2 For a counter-narrative see Sitas $(1986 ; 1990)$. Masilela (1988) offers a tactical critique, arguing that CCMS provides a theoretical bridgehead between Europe and Africa. Where Kerr (1989) affirms CCMS's popular ideologically tactical outputs like Rethinking Culture, Kistner (1989) criticised this anthology as opportunism in CCMS's search for "legitimacy". Wright (2003), in contrast, was empowered by CCMS's activist, communityorientated performative approach. 
mobilised for resistance, for these critics, was improbable. CMS in the early 1980s itself battled against leftist notions of over-determination. Liberal detractors however supported the stretch of the Centre's anti-apartheid work which included union, Mass Democratic Movement and civic groups. The right was indicated by Security Police surveillance of our activities ${ }^{3}$. At the level of the institution, paradigm fundamentalism later predominated. Initially highly supportive literary scholars were replaced by a new generation in the late 1990s, some of whom claimed the (undergraduate) field as a mid-wife to English Studies; and globally, journalism educators accused CMS of misunderstanding the empirical nature of the world and how journalists are expected to report on it (Windschuttle 1997, 1999; see replies by Tomaselli and Shepperson 1999; Strelitz and Steenveld 1998).

The Centre was however mobilised by its many supporters as a means of interrogating all these positions. UKZN was already exploring 'culture' in very particular and different ways in labour studies/union activism (Sitas 1986) and in popular (media) education (see Prinsloo and Criticos 1991; Deacon 1992; Criticos and Quinlan 1991).

The problem that the older disciplines have with CMS relates to its transdisciplinarity. C. Wright Mills (1970) first wrote about the 'sociological imagination'. Then, David Harvey (1988) examined the 'geographical imagination'. The 'literary imagination' - the Big Text with a capital ' $T$ ' dominated the Humanities until Richard Hoggart (1957) broke with this paradigm in the 1950s to form CCCS. This Centre had studied popular mass-produced texts - low culture read by ordinary people, not just the reified 'civilizing canon' that then dominated academic attention. In South African literary studies the break was effected by writers like Nadine Gordimer, J.M. Coertzee, Athol Fugard, Njabulo Ndebele (see e.g., 1984) and Steve Biko (1978), while the exiled Ntongela Masilela (1987; 2000) kept an eye on developments more broadly.

\footnotetext{
${ }^{3}$ This took the forms of hijacking our mail, interrogating staffers and confiscation of documents when re-entering South Africa at border posts, harassment by Security Police of CCMS students; refusal of visas to visitors; and informers were everywhere. But state agencies also studied our published work and granted Ruth Teer-Tomaselli (1992) direct access to the SA Broadcasting Corporation for her $\mathrm{PhD}$ research. We conducted our research in the open and transparently notwithstanding overarching repressive conditions.
} 
The notion of conflict in lived cultures was pioneered by E.P. Thompson (1968) (History) and Raymond Williams (1958) (Drama, Media Studies) who opposed the hegemony of the Text, the canon. CMS claimed the phrase 'media imagination'. This appropriation includes audiences and readers as makers-of-meaning. This is a decoding emphasis that incorporates the circuit of culture model - text, production, regulation, transmission, legislation, reception, etc. (Du Gay 1997). This shift from text to context cautions the encoding emphasis that assumes that Texts exist without reference to readers, producers, channels, regulators or markets. Reception analysis as applied in CMS thus examines how readers-as-citizens make sense of texts rather than only how the scholar makes sense of them (see, e.g. Strelitz 2006; Roome 1997, 1999; Tager 1997, 2010, Milton 2011). The personal relation to what is being studied is thus decentred from author to communities of readers - and via audience measurement - back to producer.

A holistic CMS imagination examines the relationship between Texts (print, film, oral, TV, digital etc.) and Contexts (political economy, society, economics, politics, institutions, policy and regulation) as well as how meanings are made, represented, interpreted and (re)circulated. CMS is reducible neither to the Text nor Context, nor to the interpreter. These emphases are what confers upon CMS a conceptual difference to other disciplines with which it nevertheless interacts. The Humanities tend to study via 'close readings' 4 forms of representation, whereas the social sciences examine processes and conditions out of which texts arise. How to mesh the two is the province of CMS. This interaction is at the root of significant epistemological differences with the disciplines on which it has drawn.

CMS has now been disciplined globally into an undergraduate teaching syllabus, especially in language and literature departments that are (re-)textualising the field. The instrumentalist educational objectives that brought this about have largely evacuated CMS's underlying critical, political and ethical principals. CMS now comprises distinct epistemological trajectories, each allied with clear sets of competencies aligned to three cognate inter-paradigmatic tracks:

\footnotetext{
${ }^{4}$ This term is used by my literary colleagues at UKZN. It encodes a post-Leavisite-type of personal relation to the text under study.
} 
a) communication studies (the 'how to' in the professional institutional media world, including audience measurement techniques, communication strategy, and generation of communication policy etc.);

b) media studies (the critical analysis of media-society relations, regulation, policy, political economy etc.); and

c) cultural studies (the epistemological underpinning of media studies, that also offers a critique of communication studies). CMS includes analysis of representation and reception studies and is now concerned with how audiences, rather than producers, make meaning.

One of the outcomes of the literification of CMS is the paradigm assumption that CMS (at undergraduate levels) is an addendum to English Studies/literature (i.e. 'editing and writing', textual analysis, media appreciation, close readings of the visual). However, the epistemological contradictions are clear:

Communication Science derives from a positivist social and organisational psychology pursuing administrative research largely helpful to corporate and vested interests;

Communication Studies initially derives from the Frankfurt School of sociology and is hostile to administrative research (see e.g., Mosco 2009);

Media Studies is sourced from Marxism, politics and economics, history etc. and is largely studied via semiotic methods (see e.g., Hall et al 1978);

Cultural Studies initially derives from critical analysis of popular texts, and later, history, sociology, anthropology, psychoanalysis etc.

Cultural Economy asks the question, "How does cultural studies do economics (Grossberg 2010: 108; see also du Gay and Pryke 2002; Laden 1997; NarunskyLaden 2010).

CS, loved and hated, is often considered to constitute the thin edge of the wedge, the means by which the central civilising pillars of the Humanities are being trivialised, invaded and bastardised (see, e.g., Windschuttle 1999; Willoughby 1991; see also Frost 1988; Louw 1989). 
CMS represents for some the new barbarians clamouring at the gates -some sceptical literary scholars belittle it as 'sociology' - as if that's a curse on the sanctity of the Text. For Alan Sokal (1995), it is certain inflections of postmodern 'lit crit' that trade on 'pomo gibberish' (Pollitt 1996) that personify the 'barbarian hordes'. Here, a scientist proved that when some theories migrate between disciplines they can be semantically engineered into convincing left-wing 'charlatanism and nonsense'. Having exposed CS's semantic Achilles heel, Sokal (1996) calls for a reclamation of the Left's Enlightenment roots.

English literary scholars of the late-Nineteenth and early-Twentieth Centuries like Matthew Arnold, T.S. Eliot and F.R. Leavis responded to the political turbulence, moral disorder and social anarchy of the underclasses, created by the Industrial Revolution in the late 1800s, by attributing these to the breakdown of cultural values - "the best that has been thought and known in the world" (Arnold 1971: 65). Subsequent scholars cleansed this once new tradition's political/cultural concern and objectified culture as something to be found in a book, or on a stage, something disconnected from the political idea of a 'centre of authority' managed by the educated minority on behalf of the ordinary majority.

In South Africa, the champions of the 1950s New Criticism were, thirty years later, defending it as 'traditional criticism'. By suppressing the history of New Criticism, many subsequent scholars presented this approach as timeless. Forgotten was the acrimonious struggle by which this critical method first had obtained legitimisation. '[T]raditional criticism' focuses attention upon a personal relation to literature. The vital and necessary connection it once had with larger realities had been severed, as was its capacity for cultural mobilisation (Vaughan 1984: 46). Challenges to this paradigm were to be one of the stimuli to CMS during the 1950s at Birmingham and from the mid-1980s at NU (see, e.g., Chapman et al 1992; Visser 1984).

Structuralism holds that individuals live and experience conditions in and through categories, classifications and frameworks. In contrast, culturalism derives from different premises - no less concerned with questions of struggle, class and power. Where structuralists argue, after Karl Marx, that people make history under conditions not of their own making, culturalists insist that people are active agents in the making of their own histories-from-below. The former is 
pessimistic, assuming that individuals are bearers of the structures that speak and place them; the latter is optimistic as people are argued to emancipate themselves through communality of experience. Thompson (1968) lays greater emphasis on concrete studies of resistance among the underclasses than on theoretical elaboration. Ideology is not, for this approach, a major theme. 'Experience' occurs within class-as-consciousness, and is a collective way of making sense, a way of negotiating reality, of knowing about an epoch.

Like squabbling twin siblings, the two approaches developed simultaneously in response to Stalinism. As Johnson's (1979: 54) landmark statement expresses it: "Neither structuralism nor culturalism will do!" This maxim underpinned the CCMS project from inception. CCMS additionally emphasised indigenisation (rather than Africanisation), while Masilela (1988) appealed for a 'nativisation' that involves the re-orientation of intellectual and historical perspectives of CMS in terms of African cultural trajectories and histories (see also other debates on Afrocentricism: Sesanti, 2009, 2010, Tomaselli 2011; Shepperson and Tomaselli 1999). Issues of identity conferred on Africans and the African diaspora are discussed in Wright (2003), and in Tomaselli and Wright (2011).

\section{Travelling Theory}

Theories and paradigms travel, and as they migrate they mutate and change, reconstitute initial emphases, and even forget their origins. The outcomes can be both affirming and unsettling, unruly and disruptive. The way that CMS travelled 'to' and spread 'within' Southern Africa (see e.g., Zhuwarara et al. 1997), is little different to its trans-Atlantic mutations, and the trajectories and emphases it assumed in Australasia, Scandinavia and Asia. When such theories do 'arrive', they are often: a) unproblematically applied in unreconstituted forms to different conditions at their destinations; b) appropriated by politicians and cultural commissars for party political ends; c) problematised and indigenised to embrace local frames of reference; and d) tamed and relocated into reader-response relations (i.e. the 'new' practical criticism that re-introduced the idea of Text, whether read or made by the reader/author). All else is lost in postmodern parody (Sokal 1995). 
The largely unpublished late 1980s workerist critique of CCMS occurred in the face of the CMS informed counter-argument. For CMS, semiotics provided a critical weapon against both apartheid social practices and dominant social constructions of reality. It was necessary to contest hegemonic forms of representation to enhance cultural work in the labour movement. Structuralist semiology, in contrast, is indeed guilty of determinist and de-humanising tendencies. But it was only later that the actual differences between structuralist semiology and pragmatist semiotics were elaborated upon in an attempt to bridge this gap (Tomaselli and Shepperson 2000a). By that time, however, the debate had largely subsided in labour sociology, though it continued in publications debating black performance (see, e.g., Gready 1994). The achievement of democracy in the mid-1990s had provided a new-found freedom for the left to rethink its earlier constituency-led paradigmatic positions. Epistemological ironies abounded, however. Where the workerists accused semioticians of conceptual fascism, language scholars applied semiotics 'clandestinely' (by not naming it because of semiotics' 'subversive connotations') in their study of repressive apartheid agencies (Pokpas 1989; 1992).

This brings us to a discussion of indigenisation, or 'nativisation', to use Masilela's term.

\section{Appropriations and Indigenisation}

With some exceptions, CMS discussions, especially in South Africa, tend to be conducted within frames drawn from French, British or US approaches, while nevertheless claiming a localised emphasis in the titles of such books and articles (e.g. Nuttall and Michaels 2000; Cooper and Steyn 1996; see also Zegeye and Vambe 2009 who offer a very direct, if noisy critique, of scholars like Mbembe, Appiah, Mamdani and others).

In its extreme form, the indigenisation argument maintains that theories and approaches developed at the metropoles are irrelevant for Africa. This appraisal is difficult to rebut when

confronted with exhortations on the recovery of 'Indigenous Knowledge Systems' (IKS). This is because theory, like other forms of writing, has intimate relations to the particular structures and struggles of societies. This argument, however, under-estimates the extent to which many African nations incorporate elements of modern capitalist states, and the extent to which they 
have moved along the path towards modernity (Muller and Tomaselli 1990) and even postmodernity.

Western conceptual exploration has obvious intellectual (and sometimes imperialist) benefits, even for Africa. Serious problems occur, however, when such unreconstituted models, theories and paradigms developed to answer problems and offer explanations of processes elsewhere, are applied in Africa irrespective of local ways of making sense and doing things. The development literature is replete with descriptions of failure resulting from inappropriate theoretical applications.

\section{Africa Looking at the West Looking at Africa}

Amongst Africanists in the diaspora is an image that Africa is a purely European construct. In response, some African scholars and politicians resenting their status as Other have constructed an alter ego - an essentialist identity developed in response to exploitation by the Western Same. This identity vigorously propagates analytically uncontestable notions like 'authenticity', IKS, and the pre-Lapsian idea of 'African values'. The long colonial relationship is however much more contradictory than simply one of exploitation. Paternalism, cultural cross-pollination, assimilation, exclusion, segregation and adaptation were different strategies adopted within different spheres of interaction at different times. Sometimes one of these has been a major imperial outcome, as evidenced by the existence of linguistically-defined Francophone, Arabophone, Anglophone and Lusophone regions.

Conversely, ordinary people have developed strategies for accommodation, resistance and self-support. Essentialist argument allows them to blame Africa's ills on the West, no matter the source of these problems and to propound Afrocentricsm as a counter-discourse (Asante 1988; Sesanti 2010). The value of CMS as bequeathed by CCCS and its international reconstitutions is that meanings are never fixed; cultures (in the anthropological sense) are being constantly reinvented both from within and through their myriad encounters with travellers of all kinds including academics, politicians and via media, education, UNESCO, the Bretton Woods institutions, and transnational border information and trade flows, and so on. Just as there is no one CMS internationally, there can never be a single African CMS. 
What CMS in Africa needs do is to treat Africa as dynamical rather than static, as heterogeneous rather than singular, as always in question rather than always having been known, as known only through global comparisons, as living rather than mortified or naturalised, and therefore as incomplete and imperfect rather than either inferior or idealised [UND 1996]. While metropolitan theory is always useful, however, adaptation to local contours must engage local theories in a dialectical manner.

\section{Media Studies and Meaning}

CCMS's mandate was to develop graduate research that would: i) theorise the mobilisation of 'culture' and 'media' in the service of the anti-apartheid struggle; ii) offer a hub for interdisiplinary modules; and iii) work with civil society. CMS globally had struggled to reclaim these sites during the Thatcherist and Reagan era and to restore the integrity of the public sphere for all constituencies (see, e.g., Rønning 1997). All cultural and media sites, we argued, should be contested, not simply abandoned to hegemonic forces as had been the case amongst most South African English-speaking universities. Below, we discuss a number of phases through which CCMS has developed, reflected and shifted.

\section{Phase 1: Tooling Up, Anti-Apartheid Struggle (1985-1990)}

The inaugural year, 1985, developed a core theoretical approach linked to: i) curriculum design; ii) an international publication strategy; iii) identification and enculturation of contributing academics; iv) a strategy to negotiate the international cultural and academic boycott ${ }^{5}$; and v) recruitment of the first batch of students to start in 1986. The curriculum was debated by

\footnotetext{
${ }^{5}$ Amongst the strategies to negotiate the boycott were the promotion of Critical Arts globally, which as one of the few South African published explicitly anti-apartheid journals quickly gained a sympathetic global readership. Other such journals then published included Work in Progress, Africa Perspective and Perspectives in Education. Anti-apartheid activists were appointed as Critical Arts' "Overseas Organisers" and when the editor travelled to the USA, his tours were arranged by his left-wing publishers (Smyrna and Lake View Press) in liaison with antiapartheid, human rights and Africanist organisations. A similar strategy was developed by the United Democratic Front which argued that it was the regime, not the democrats that needed to be isolated. Regarding CCMS itself, both Johnson and Hall had been approached informally on the idea of the Unit. A key long-term advisor was Masilela, then in exile in Poland.
} 
academics from many Faculties and published as occasional papers, initially funded by small grants volunteered by departments across the University as a whole. Seven of the 23 contributions were compiled into Rethinking Culture (Tomaselli, 1988). The then bi-annual Critical Arts supplemented these papers, and grounded the ongoing critical intellectual base of the Centre. Some of the epistemological imperatives signposted here were later picked up the South African Theatre Journal. An international book series edited by CCSU's Director between 1986 and 2002 published six original titles on media research, with reprints of three titles up to $2005 .^{6}$

The initial batch of modules included a rather eclectic list: i) Science as a Cultural Expression (taught by three Physics lecturers ${ }^{7}$ [one of whom was employed in Architecture], a topic that did not find easy acceptance in these lecturers' home disciplines); ii) Culture and Literature, and iii) Walter Benjamin and the Idea of Historical Projection (were taught by lecturers from English ${ }^{8}$ ); iv) Film, Video and Cultural Production was homegrown; v) Thanatology: Death and Ideology (was offered by a medical School psychiatrist); and vi) Culture and Community Health (was taught by the Medical School and Social Science). These were modules that could only fit into an eclectic interdisciplinary environment that elevated critique and praxis over content. Contributing lecturers, to use the language of the theme editors, were 'migrants' engaged in 'responsible interdisciplinarity' in creating vectors of conceptual interaction between different disciplines.

Because the tooling up phase coincided with the most intense period of anti-apartheid struggle, CCMS not surprisingly shifted its focus from a 'pure' cultural studies analysis of 'texts', towards a concern with the actual production and circulation of media and their messages. First, was a concerted focus on analysing the way the State and business sectors used the 'establishment' media to promote their interests. Second, CCMS focused on emergent antiapartheid media. From the latter grew the Durban Media Trainers' Group (DMTG). DMTG, was

\footnotetext{
${ }^{6}$ This series was facilitated by Michael Traber of the World Association for Christian Communication (London), in conjunction with Anthropos Books (Cape Town), James Currey (London), Lake View Press (Chicago). This initiative that was later followed through by International Academic Publishers (Colorado) and was modeled on CCCS's early relationship with Hutchinson which published their early books and which popularised CMS across the globe.

7 Derek Wang, Don Bedford and Peter Barrett.

8 Michael Vaughan and Peter Strauss.
} 
established by four Durban activists as a project geared to expanding the pool available to produce media for the then emergent United Democratic Front (UDF) and Congress of SA Union activities in Natal (Louw et al. 1989; Mackay and Louw 1990). Thousands of media activists were trained during the late 1980s and early 1990s by organisations like DMTG, Grassroots (Cape Town) and The Other Press Service (TOPS) (Johannesburg). These projects were affiliated through the National Media Trainers Forum, which was concerned with how the media could be used to promote the anti-apartheid struggle as well as with how a reconfigured media might be deployed to develop a post-apartheid South Africa (Louw and Favis 1991; Louw and Mackay 1990). CCMS and DMTG activities integrated when Eric Louw joined CCMS staff and students to run media training courses within DMTG's activist training programme. This increased the pool of trainers available to DMTG, provided CCMS students with real world experience, and brought together CCMS' (mostly privileged) university students with (mostly poor) activists from the black townships. This work, of course, also provided CCMS academics and postgraduate students with a wealth of opportunities to research the emerging UDF/COSATU struggle and its media dimensions. Indeed, the UDF had decided to make media activism central to its national strategy (Van Kessell 2000), and the three training organisations were central to this objective.

Phase 2: Consolidation, The Policy Moment (1990-2002)

In 1989 the Centre consolidated a more directly CMS approach as lecturers from the first phase refocused their activities back to their home departments.

The nature of the anti-apartheid struggle shifted in 1990 with the unbanning of the liberation movements. The CCMS-DMTG relationship matured into a radio training course to skill-up activists for possible careers in the SA Broadcasting Corporation. The onset of constitutional talks required that consideration be given to media (and cultural) policy issues. One outcome of this was as a compendium of studies, policy statements and manifestos entitled South African Media Policy edited by Louw (1993). At the same time it became clear that foreign subsidies for alternative media would cease. Louw was thus commissioned to conceptualise a new subsidy model, which found form in the Independent Media Diversity Trust (Louw 1992a). 
It was during this conjuncture that Bob White, then of The Gregorian University, spent six weeks at CCMS as a visiting lecturer. Working with development studies graduate, Ruth TeerTomaselli, they composed a syllabus that comprises the foundation of the current module, Development, Communication and Culture (DCC). DCC initially examined development theory and Africa, public service broadcasting and the notion of the public sphere. Students found connections between this module and anthropology field trips, and later with public health communication. By identifying the interstices between modules and connecting the commonalities, students themselves repositioned this module via 'sentient engagement' as a contextual conceptual core within which all the other CCMS modules connected.

This phase also saw CCMS working on a variety of broadcasting, film and cultural policy documents, for the Convention for a Democratic South Africa and government departments. Tomaselli brought the Film White Paper and Film Strategy Document to completion in 1995, Teer-Tomaselli served two terms on the SABC Board, and even CCMS students contributed to this policy making enterprise (Mpofu et al. 1996; Louw 1993; Shepperson and Guambe 1997). The South-South Working Group on Media, Culture and Communication, arose out of this moment, which with funding from the National Research Foundation, University of Oslo's Dept. of Media and Communication, Kopinor and other sources, linked a number initiatives into ongoing research involving the Universities of Oslo, Zimbabwe, Rhodes and the editors of Media, Culture and Society.

\section{Phase 3: An Interregnum, the Undergraduate Connection (2003-2005)}

In 2002 CCMS merged with the largely undergraduate programme, Media and Communication (M\&C) on the Durban campus. The original 1997 proposal was based on a liberal arts model in which students could mix and match from a variety of modules offered in the Faculties of Humanities and Economics, incorporating both the business of media and issues of representation. This track morphed after 2005 into the Management and Communication Programme coordinated by the Institute for Organisational and Labour Studies led by sociologist Gerry Maré. A second track comprised a purely liberal arts model. 
When CCMS had earlier merged with M\&C (Durban) between 2002 and 2005, the programme, offering basically short undergraduate courses, was totally restructured and revitalised. By mixing and matching between the three tracks (Communication Studies, Media Studies and Cultural Studies) students now prepared themselves for entry into the business of media, creative industries, and research and marketing. Political economy, audience studies and critical strategic communication (incorporating the new area of cultural economy) were offered to equip students to enter and shape these sectors. Specialist appointments were made to service this uniquely (critical) professional track in which most students were interested.

The merger with the University of Durban-Westville (UDW) in 2004, however, saw a 'bring 'n share' response that re-oriented the previous programme into 'reading media', as the hard-nosed media lecturers were re-balanced by new entrants from UDW literary studies. The African context was largely erased and a Northern emphasis re-emerged. This resulted in a parting of ways and the re-establishment of CCMS to recover what the guest editors of this issue phrase as an 'ethical turn in the praxis of Cultural Studies'. The result of the merger was the 'settling of CMS' into a taught undergraduate syllabus in Durban largely based on the reading of texts, though some lecturers continued teaching political economy and media studies. The politics of praxis, social mobilisation and action research, was erased, however.

Countrywide after 1990, the permissive practice of 'teaching' a topic that is disconnected from its disciplinary subject and disengaged from the roots of its disciplinary/field roots, engrained contradictions caused by mergers with other institutions. The influx into media studies of literature lecturers not grounded in communication or media studies and their respective epistemological histories significantly shifted the paradigm to which undergraduates were exposed. The tendency of literary scholars is to start with a didactic text, refer back to whatever they 'know' about 'media', and the topic gets interpreted and represented in terms of that selfreflexive background knowledge.

A discipline/field is like a language or grammar (langue) and the various subjects/topics/modules are a parole (accent) that principally articulates its disciplinary deep 
structure, which through research, contests and revises it. When one talks about students having to make the connections between the different modules (CS, communication, media studies), we mean that they do so by indexing the common langue. When that parole becomes disarticulated from its langue, and becomes 'spoken' by a different discipline, we come to effectively teach the new langue, irrespective of the content of our teaching. For example, the disarticulation of cultural studies from its historically grounded roots and its rearticulation with literary theory reorientated the subject as something 'done in class' rather than 'in world' as it is intended. The topic was now studied 'in English Studies' -- the langue of the supposedly media studies undergraduate programme at Howard College -- irrespective of the authenticity of the published sources from which the course content is derived. Ironically, the new emphasis on 'reading media as text' is lost upon those who profess their former langue in the stranger terminology of their newly-adopted topic. There's a ball, a bat, and wickets; but it just isn't cricket! ${ }^{9}$

\section{Phase 4: Coming of Age, Critical Indigenous Professionalisation (2005-2012)}

The re-established Centre attracted National Research Foundation funding for the Rethinking Indigeneity foci and ongoing USAID support via Johns Hopkins University (JHU) for the establishment of a public health communication and development communication curriculum. This initiative arose out of the work done by CCMS staff, students and graduates in the public health sector in the 1990s (see Parker 2005; Delate 2001, 2007; Tomaselli and Chasi 2011; Dalrymple 1997). The Centre aimed to develop a model of development communication based on dialogue rather than monologue, horizontal rather than vertical information sharing, social rather than individual change, and equitable participation, local ownership, and empowerment (Gray-Felder and Dean 1999).

\section{Humanities: A New Imaginary}

The Humanities deal with ways of knowing that are different to those found in the Sciences and Social Sciences. The texture of daily lived experience is the Humanities' remit. Social Science techniques are crude by comparison and cannot measure human qualities, structures of feeling,

\footnotetext{
${ }^{9}$ My thanks to Marc Caldwell for this insight.
} 
or quotidian life. The social sciences do however provide the facts that can be ignited by significant insights as provided by various forms of writing enabled by the Humanities (Hoggart 1970). The Humanities and Social Sciences, while often administered by the same Faculty structures, tend to operate separately when it comes to methodology, if not always theory. Where the Humanities may best be described as engaging in 'close readings' (i.e. qualitative, texts, representation and languages), the social sciences are more likely to be engaged in analysis of processes (i.e. contextual, quantitative, structural). Rarely do the two interact, though when they do, the best of both paradigms can deliver rigorous trans-disciplinary analysis of arguably wider import.

One of the mechanisms available to addressing unresolved problems in post-apartheid society is to be found in mobilising the Humanities to address pressing social problems. This objective, however, is compromised in the popularly perceived Eurocentricism of disciplines that draw their inspiration from primarily Western epistemological histories and which are very cautious of the essentialisms threatened by discourses propagated by intellectuals promoting IKS. Where the objects of study may now be (South) Africans, their theory and methodologies (and the conceptual assumptions that underlie these) remain those of the (post)industrial, Cartesian-led ontological world. It is within this indeterminacy of translation that the current conflict occurs between those who are intermediaries for the different paradigms and who tend to remain rooted in one or the other (cf. Mudimbe 1988).

We often hear in Faculty meetings defensive exhortations in the face of threats that Philosophy is the raison d'être of the University, that Classics is its soul and that the Humanities is the framework that invests meaning to the entire enterprise. Literature is that which keeps the barbarians at bay and the study of the canonical Text is what legitimates the entire project as it underpins 'cultural and civilising values'. This is an imaginary that informs the old paradigm.

How to constitute the Humanities in an era when students think of them as edutainment is a key task. For too many South African students, studying is simply understood as 'doing time' as a way of securing a certificate, which they assume is the open sesame to highly paid employment. Added to these perceptions is the belief that the Humanities are useless, or at least 
of limited vocational value, if not unnecessarily negative/derogatory in orientation (see ASSAF 2011).

Below, are some examples that indicate how this new imaginary developed within CCMS. These examples are offered as ways of explaining a specific academic venture, and it is quite likely that other centres can offer their own examples on as many, if not more, fronts (see e.g. Starfield 2002; Steenveld 2004; Nuttall and Michaels 2000; De Kock et al. 2004; Kriger and Zegeye 2001; Cooper and Steyn 1996; Wasserman and Jacobs 2003; Van Eeden and du Preez 2005; Strelitz 2006).

\section{Example 1: Revitalising Ecumenical Newspapers}

Work undertaken over a 25 year period for UmAfrika, an isiZulu-language weekly published from the Marianhill Mission, Durban, inaugurated CCMS's praxis. Students worked on three separate commissions, in 1986, 1990, 2010. The 1986 study aimed to revitalise a once vibrant and politically significant paper that had lost its way (Tomaselli et al. 1988; Louw et al. 1989). Application of alternative press theory, reorganisation of the newsroom, and other practices repositioned the paper regarding its ecumenical readership. The 1990 study advised on how to consolidate its now massively enhanced market position vis-à-vis political conflict in the context of a provincial civil war, financial pressures for viability once stability was ensured, and an extension of its advertising base to include corporate capital, especially from the growing black capitalist class (Louw et al. 1990). The 2010 intervention aimed to balance corporate and Mission Institute objectives as the paper had entered into a user agreement with Media24, a multinational South African-owned media conglomerate.

What students learned in these interactions encompassed the micro circuit of culture relating to the paper: editorial assumptions, story selection, sources, regulation, production, distribution, competitors, readers, interpretation and consumption. The research team not only facilitated successful action research interventions, but they also generated new methodology (Tomaselli et al. 1988). This project became the basis of our next study, The Alternative Press in South Africa that theorised the wider environment and explained how the 
community-based press became the fulcrum of democratic mobilisation in geographically/ethnically defined areas across the country (Tomaselli and Louw 1991a).

Work done for the SA Catholic Bishops Conference extended the life of New Nation (if briefly into the post-apartheid era) (Tomaselli 2000; Tomaselli and Teer-Tomaselli 2003). The UmAfrika and New Nation projects forged our early attempts at action research aimed at very specific and concrete outcomes. These were followed by work on public service broadcasting (Mpofu et al. 1996) and media policy (Louw 1993; Teer-Tomaselli 2004) as means of shaping outcomes as the country headed towards its first election in 1994. This work gained a new resonance in 2010 when the liberation government announced its intention to roll back press freedom, and when the national broadcaster again became a site of extended political squabbling and financial meltdown. These anthologies are reminders of what had been, what could have been, and what was popularly negotiated during the moment of transition (see, e.g., Olorunisola and Tomaselli 2011). CCMS now found itself opposing the new state's repressive tendencies, again along with a host of new media activist groups.

\section{Example 2: Defending Peace}

A study conducted for the End Conscription Campaign (ECC) was used by ECC lawyers in their opposing of the Minister of Defence's refusal in 1987 to cease his dirty tricks campaign against the organisation (Graaf et al. 1988). An analysis of militarisation, hegemony, and the social constriction of the enemy underpinned analysis of anti- and pro-war publications then in operation both within and external to South Africa. This study provided the backdrop to a dramatic Supreme Court victory by ECC. We had argued in opposition to the Minister's media expert, Elsabe Pepler (n.d.), that she had woven fiction and non-fiction via an impression of scientific method assuming a transmission model of communication into an utterly flawed narrative on ECC. Interrogating her thesis and method, which was part of the court documents in the form of an affidavit, we developed from it a theory of disinformation that was used by the ECC legal team against the Minister. By applying Peirciean semiotics as popularised by Hall (1980) in his seminal encoding/decoding model, we convincingly demonstrated to the Court that it was the thesis and the Minister and not the ECC media that 
were at fault. The result was the cessation of the dirty tricks campaign, simultaneously followed by the expected banning of the Campaign (Tomaselli and Louw 1991a).

\section{Example 3: Mining: Health, Safety and the Culture of Hazard}

Previously an industrial electrician on the mines, Arnold Shepperson (2008) addressed the question of why qualified engineers dismissed the experience of unqualified workers on matters of hazard and of safety. Our study, sponsored by the Safety in Mining Research Council, examined how hazard and safety were discursively constructed by the industry, how this shaped a narrow repertoire of technical responses, and why these so often failed in practice (as investigated by the Leon Commission) (Leon et al. 1995). What is of relevance here is that Shepperson considered it necessary to examine the concept of 'culture', from early English novelists to theoretical considerations of historical materialist writers like Raymond Williams (1958), in order to grapple with how hazard was understood by the mining institution. Shepperson argues via Peirceian pragmatism that the idea (and practices of) safety are social constructs appropriately examined within the Humanities in relation to Engineering. For Shepperson, the problem was not located solely in the realm of the technical, but mainly in how engineers 'make sense' of safety and hazard and why they reserve for themselves the sole right to diagnose danger/safety in the face of other (experiential) opinion which, as Shepperson argues, often turns out to be better placed. The division of exposure to danger (linked to the division of labour) were issues that Shepperson was unpacking via his cultural analysis to understand engineering discourse regarding health and safety. ${ }^{10}$

\section{Example 4: Critical and Indigenous Methodologies}

10 Gary Richmond writes: "Arnold's work puts SA on the map in terms of Peircean studies. For example, his work is occasionally referenced on peirce-1, something which was rare before the Critical Arts theme issue. To the extent that Peircean studies take a more general foothold in American and global philosophy, I believe Shepperson's work will become increasingly relevant. Certain signs that this foothold may be beginning have occurred including the recent acclaimed release of an autobiography of President Obama's mother whose dissertation advisor was John Dewey, the most famous 20th century pragmatist. In turn, Dewey was the student of Peirce for a time in Chicago. It is very possible that Barack Obama has been influenced by philosophical pragmatism, which several articles written in the last 2 years have argued" (pers comm. 9 May 2011; see also Richmond 2008). 
Too often, it is forgotten that the word 'research' is one of the dirtiest words in the indigenous world's vocabulary. Linda Tuhiwai Smith (1999) calls for a decolonisation of research methodologies to counter this image. "Decolonization is a process that engages with imperialism and colonialism at multiple levels. For researchers, one of those levels is concerned with generating a more critical understanding of the underlying assumptions, motivations and values that inform research practices" (Smith 1999: 20). Smith urges researchers to disrupt the rules of research towards practices that are more respectful, ethical, sympathetic and useful vs. racist practices and attitudes, ethnocentric assumptions and exploitative research. Similarly, a Critical Indigenous Qualitative Research approach can be applied along with interpretive research practices that aim to be ethical, transformative, decolonising, and participatory (Denzin et al. 2008). A long-term project working along these lines tells the story of how CCMS students are decolonising research through providing ways in which a study of !Xaus Lodge, co-owned by two indigenous communities has, in working with the lodge operator, developed i) a model of community/lodge partnerships, ii) marketing strategies sensitive to indigenous concerns; and iii) aimed at local empowerment and sustainable development. The model asks what kinds of community-lodge partnerships can be designed to best negotiate the demands of marketing on the one hand, and the symbolic, spiritual and livelihood needs of a cultural community of practice on the other. The economic and financial impacts of the new business model can be accurately measured and students working on this project not only develop new methods sensitive to issues of indigenous (self)representation, but they also meet the criteria imposed by commercial imperatives while maintaining a balance between the two (see, e.g., Finlay 2009; Dyll-Myklebust and Finlay forthcoming).

The flip side of critical indigenous methodologies is found in the idea of 'indigenous knowledge systems'. IKS seems to offer a discourse responding to a particular political moment that evokes a communal cultural memory that resides in the Jungian concept of the collective unconscious. For science, IKS might present itself as intuitive, an emotive discourse in which individuals try to culturally locate themselves in dual dimensions. The first is modernity, the second is an imagined, pre-modern (anti-Western) ontological dynamical world. The result, sometimes, might be a contradictory consciousness in which a discursively 
fixed indigeneity prevails as public memory over the contemporary reality of an individuated, consumer-led, postmodern subjectivity. To use a stereographical metaphor, such individuals encounter both worlds simultaneously, but want others to reside within (or at least recognise) their re-construction of a different particularistic ontology deriving from a different but intersecting past. It may be argued that IKS require different systems of verification, but the issues are: i) how to validate the results and share them for the good of the general critical citizenry; ii) how to valorise the 'evidence of experience' claimed by autoethnographic researchers in a non-essentialist manner (see Berry and Clair 2011); and iii) how to deal with a self-referential pre-Lapsarian-type discourse that exists entirely within its own authority, one that assumes a priori 'purity', does not permit critique, and which cannot be faulted because its claimed 'indigenous' status. A reckless indigenisation of theory that ignores critique often results in genocide ${ }^{11}$, no matter the society, mode of production or educational level.

\section{A New Humanities}

The post-Cold War conjuncture has turned cultural studies (one of the contemporary grand narratives impacting the Humanities) into a commodity as it is now often taught as a playful form of writing, recreation and consumption. It is undoubtedly European, US-centric and Western, though now appearing here, there and everywhere. In South Africa at least, the Humanities, was implicated in colonialism, a link which it retains in the face of IKS and its own Africanist ideologues. The Humanities thus remain suspect in the eyes of the newly politically liberated.

In its ungrounded guise CS has largely lost its social relevance, its socially strategic potential and its objective of popular empowerment as it is now taught, especially at undergraduate levels. Postmodernism, properly done, is basically in the business of critique, but to be socially relevant it needs to recover position, rights and justice. Diagnosing what's wrong can only occur in terms of discussions about what is right. Conversely, when taught as celebration of the trivial and banal

\footnotetext{
11 My thanks to William Ellis for this last particular insight, lecture, CCMS, Durban, 29 June 2011.
} 
it loses its democratising focus. Recent interventions, for example, Grossberg (2010), have attempted to rectify the slide towards the celebration of banality.

Certain recent forms of CMS are, however, masked under often impenetrable jargon known predominantly to the postmodern sign community. Sections of this community have returned CMS to analysis of the personal relation to particular texts under study. This opacity refuses the empirical, is scornful of material realities and of ethical position. These are the very sites for which democracy is constituted. Recovery of CS as an 'unruly' pedagogy', however, remains ever-present. This was the underlying message that emerged from the June 2011 Association for Cultural Studies PhD Institute held at the University of Ghent, Belgium. Speakers at this event recovered the period of the pre-post past, that more conceptually stable time when academics engaged in analysis rather than just celebration.

The new Humanities paradigm would be much more relevant, pro-active and acquisitive:

- This new imaginary would be all-inclusive while simultaneously democratising, useful, generating employable (critical) graduates. It vests authority in the citizenry rather than solely in Textuality, Authority and Bureaucracy.

- It would admit critical and indigenous methodologies (Denzin et al. 2008) and invest analysis with new, diverse, pluralistic, ways of making sense.

- The new imaginary would examine texts in relation to contexts, power relations and outcomes of contestations, as a means of equipping graduates with expertise to both successfully manoeuvre within institutions for career purposes, but also to help shape them towards more democratic and ethical behaviour in larger society, while taking into account the plurality of ontologies and identities that now jostle for legitimation and power in a post-modern world.

What is to be protected is not 'high culture' or abstract Western notions of civilisation and hegemony of the canonical Text (often argued to be the repository of civilisation). Rather, the new imaginary requires that instead of defending paradigm fundamentalism and Western civilisation (and its Philosophy made possible by the Enlightenment), that we rather critically 
engage this corpus and build a more inclusive dynamic CMS that responds to the myriad contexts in which the diversity of multicultural generations find themselves. Cultural studies as celebration is bereft of critique, as the legitimation of banality it loses sight of human rights, and as pomo gibberish, it rearticulates resistance as consumption, consumption as democracy and democracy as autocracy. It is then implicated in new hegemonies rather than in a constant state of liberating subjects from this recurring condition. 


\section{References}

\section{Primary Sources}

Richmond, Gary. 2011. Personal Correspondence, 9 May 2011.

\section{Secondary Sources}

Althusser, L. (1971a). Ideology and Ideological State Apparatuses. In: Lenin and Philosophy and Other Essays. London: New Left Books, pp. 127-188.

Althusser, L. (1971b). For Marx. London: Allen Lane.

Arnold, M. (1971). Culture and Anarchy: an essay in political and social criticism. University of California: Bobbs-Merrill.

Asante, M.K. (1988). Afrocentricity. Trenton: New Jersey.

ASSAF (Academy of Science of South Africa). (2011). Consensus Study on the State of the Humanities in South Africa: Status, Prospects and Strategies. Pretoria: ASSAF.

http://www.assaf.org.za/wp-content/uploads/2011/08/25-July-Final.pdf

Berry, K. and R.P. Clair. (2011). Contestation and Opportunity in reflexivity: An Introduction. Cultural Studies $<=>$ Critical Methodologies, 11(2): 95-97.

Biko, S. (1978). I Write what I like: Selected Writings. Chicago: University of Chicago Press.

Bozzoli, B. (1981). The Political Nature of a Ruling Class: Capital and Ideology in South Africa 1890-1933. London: Routledge and Heinemann.

Caldwell, M. (2009). Charles Taylor and the pre-history of British cultural studies. Critical Arts, 23(3): 342-373.

Chapman, M., C. Gardner and E. Mphahlele. (ed.) (1992). Perspectives on South African English Literature. Johannesburg: AD Donker.

Cooper, B. and A. Steyn. (eds.) (1996). Transgressing Boundaries: New Direction in the Study of Culture in Africa. Cape Town: UCT Press.

Critical Arts: South North Cultural and Media Studies. (1980ff). Available: http://www.tandf.co.uk/journals/RCRC

Criticos, C. and T. Quinlan. (1991). Community Video: Power and Process, Visual Sociology, 6(2): $39-52$.

Dalrymple, L. (1997). The use of traditional forms in community education. Africa Media Review, 11(1): 75-91. 
de Kock, L., L. Bethlehem and S. Laden. (2004). South Africa in the Global Imaginary. Pretoria: UNISA Press.

Deacon, R. (1992). Power, Knowledge and Community Video revisited. Visual Sociology, 7(2): $39-48$.

Delate, R. (2007). Us and them: loveLife, commercal brands and everyday life. Unpublished Masters dissertation, University of KwaZulu-Natal. Available: http://ccms.ukzn.ac.za/index.php?option=com_content\&task=view\&id=55Itemd=34

Delate, R. (2001). The struggle for meaning: A semiotic analysis of interpretations of the loveLife his \& hers billboards campaign. Unpublished Honours Project. University of Natal, Durban. Available: http://www.ukzn.ac.za/ccms/mediacommunication/pubhealthcommunication.asp?ID=15

Denzin, N.K., Y.S. Lincoln and L.T. Smith (eds.) (2008). Handbook of Critical and Indigenous Methodologies. London: Sage.

Du Gay, P. (1997). Production of Culture / Cultures of Production. London: Sage.

Du Gay, P. and M. Pryke. (2002). Cultural Economy: Cultural Analysis and Commercial Life. London: Sage.

Dyll-Myklebust, L., and K. Finlay. (forthcoming). Action (Marketing) Research and Paradigms in Partnership: A critical analysis of !Xaus Lodge. In: Tomaselli K. G. (ed). Cultural Tourism, Methods and Identity: Rethinking Indigeneity (working title).

Finlay, K. (2009). The Un/Changing Face of the \#Khomani: Representation through Promotional Media. Visual Anthropology, 22(4): 334-361.

Frost, M. (1988).Opposing Apartheid: Democrats Against the Leninists. Theoria, Vol LXXI, May 1988.

Graaf, M., Louw, P.E., Joosten, A., Murray, A., Pestana, A., Savage, J., Sutherland, C., Tomaselli, K.G., Tomaselli, R., and Urbasch, M. (1988). Hawks and Doves - The Pro- and AntiConscription Press in South Africa. Edited by Michael Graaf. Durban: Contemporary Cultural Studies Unit, University of Natal. http://ccms.ukzn.ac.za/index.php?option $=$ com_content\&task=view\&id=697\&Itemid=30

Gramsci, A. (1971). Selections from Prison Notebooks, Edited and translated by Q. Hoare and G. Nowell-Smith. London: Lawrence and Wishart.

Gray-Felder, D. and J. Dean. (1999). Communication for Social Change: A position paper and conference report. New York: Rockefeller Foundation. 
Gready, P. (1994). Political autobiography in search of liberation: working class theatre, collaboration and the construction of identity. In Gunner, L. (Ed.) Politics and Performance: Theatre, Poverty and Song in Southern Africa. Johannesburg: Witwatersrand University Press, pp. 163-198.

Grossberg, L (2010). Cultural Studies in the Future Tense. Durham, NC: Duke University Press.

Hall, S, (2009). Charles Taylor in the Archives. Critical Arts, 23(3): 374-376.

Hall, S. (1997). Random thoughts provoked by the conference 'Identities, Democracy, Culture and Communication in Southern Africa'. Critical Arts, 11(1-2): 1-16.

Hall, S. (1980). Encoding/decoding. In Hall, S., Hobson, D., Lowe, A. and Willis, P. (eds.) Culture, Media, Language, London: Hutchinson, 128-38.

Hall, S., C. Critcher, T. Jefferson, J. Clarke and B. Roberts (eds.). (1978). Policing the Crisis. Mugging, the State and Law and Order. London: Macmillan.

Harvey, D. (1988). Social Justice and the City. Oxford: Blackwell.

Hoggart, R. (1957). The uses of literacy: aspects of working class life with special reference to publications and entertainments. London: Chatto \& Windus.

Hoggart, R. (1970). Speaking to Each other: Vol 2. Middlesex: Pelican.

Johnson, R. (1979). Histories of Culture/Theories of Ideology: Notes of an Impasse. In Barrett, M., Corrigan, P., Kuhn, A., and Wolff, J. (Eds.), Ideology and Cultural Production. Great Britain, London: Croom Helm, 49-77.

Kerr, D. (1989). Subaltern Culture. Southern African Review of Books (Feb/March), 15-17. Available: http://ccms.ukzn.ac.za/images/Critical_arts/subaltern\%20culture.pdf [Accessed: 13/09/2010].

Kistner, U. (1989). Rethinking Culture. Journal of Literary Studies, 5(3/4): 387-394.

Kriger, R. and A. Zegeye. (2001). Culture in the New South Africa. Cape Town: Kwela Books.

Kronenberg, C. (2009). Contesting the Mechanisms of Disinformation, Part 1. Contemporary developments in Latin America: a South African perspective, Critical Arts 23(2): 133-152.

Laden, S. (1997). Middle Class Matters, or, How to keep whites whiter, colours brighter and blacks beautiful.Critical Arts, 11(1/2): 120-141.

Leon, R.; A. Davies; M. Salomon and J. Davies. (1995). Leon Commission of Enquiry into Safety and Health in the Mining Industry. Pretoria, South Africa: Government Printers. 
Louw, P.E. (ed.). (1993). South African Media Policy. Belville: Anthropos.

Louw, P.E. (1992a). Proposal for the Establishment of an Independent Media Diversity Trust, June, Commissioned by the Conference of Independent Newspaper Editors.

Louw, P.E. (1992b). Rethinking the leftist struggle in South Africa. Critical Arts, 6(1): 1-25.

Louw, P.E. (1989). Rejoinder to 'opposing apartheid': Building a South African democracy through a popular alliance which includes Leninists. Theoria, Vol. LXXIII.

Louw, P.E. and M. Favis. (1991). Media and Development, Paper commissioned by National Media Trainers Forum, June.

Louw, P.E. and A. Mackay. (1990). Developing a Media Awareness Program. Report commissioned by National Media Trainers Forum, May.

Louw, P.E. et al. (1990). UmAfrika Survey. Unpublished report, Contemporary Cultural Studies Unit.

Louw, P.E. et al. (1989). Media training for Natal community organisations and trade unions. Report commissioned by National Media Trainers Forum, August.

Mackay, A. \& P.E. Louw. (1990). Moves to improve the training of anti-apartheid media workers, Media Development, Vol. XXXVII, No 1.

Masilela, N. (2000). Thelma Gutsche: a Great South African Film Scholar. Critical Arts, 14(2): 49-78.

Masilela, N. (1988). Preface: Establishing an Intellectual Bridgehead, in Tomaselli, K.G. (ed.) Rethinking Culture. Bellville, South Africa: Anthropos Publishers, 1-4.

Masilela, N. (1987). The White South African Writer in Our National Situation. Matatu, (3/4): 48-75.

Mills, C.W. (1970). The Sociological Imagination. Harmondsworth, Middlesex: Penguin.

Milton, V. C. (2011). Commercialising the HIV/AIDS crisis: Public service broadcasting, rainbowism and media advocacy. In Tomaselli. K.G. and Chasi, C. (eds.) Development and Public health Communication. Cape Town: Pearson, 289-342.

Mosco, V. (2009). The Political Economy of Communication. London: Sage Publications.

Mpofu, A., S. Manhando and K.G Tomaselli (eds.) (1996). Public Service Broadcasting in South Africa: Policy Directions Towards 2000. Johannesburg: Anthropos Publishers.

Mudimbe, V.Y. (1988). The Invention of Africa. Bloomington: Indiana University Press. 
Muller, J. and K.G. Tomaselli. (1990). Becoming Appropriately Modern: Towards a Genealogy of Cultural Studies in South Africa. In Mouton, J. and Joubert, D. (Eds.) Knowledge and Method in the Human Sciences. Pretoria: HSRC, pp.272- 286.

Narunsky-Laden, S. (ed.) (2010). Cultural Economy in Post-Transitional South Africa, Critical Arts 24(1): 1-30. (Special Theme issue).

Ndebele, N.S. (1984). Turkish Tales and some thoughts on South Africa Fiction, Staffrider, 6(1): 24-25.

Nuttall, S. and C-A. Michaels. (2000). Introduction: Imagining the present. In Nuttall, S. and Michaels, C-A. (eds.) Senses of Culture: South African Culture Studies. Oxford and New York: Oxford University Press, pp.1-23.

Olorunnisola, A. and K.G. Tomaselli. (2011). Political economy of media Transformation in South Africa. Cresskill, NJ: Hampton Press.

Parker, W. (2005). 'Ideology, hegemony and HIV/AIDS: The appropriation of indigenous spheres.' PhD thesis, University of Natal. http://ccms.ukzn.ac.za/index.php?option=com_content\&task=view\&id=55Itemd $=35$

Pepler, E. (n/d). Alternatiewe Media in Suid-Afrika met Verwysing na Plakkate. Unpublished MA Thesis, Rand Afrikaans University.

Pokpas, L. (1992). Trading signs: semiosis in the media. In Van den Bergh, N.J.C. (Ed.), The Semiotics of Political Transition. Port Elizabeth, South Africa: Vista University.

Pokpas, L. (1989). Translating the voices of the voiceless: semiotics and the task of the cultural activist $A L A L$ November: 26-29.

Pollitt, K. (1996). Pomolotov Cocktail, The Nation. Available: http://www.imsc.res.in/ jayaram/Sokal/pollitt.html

Prinsloo, J. and C. Criticos. (eds). (1991). Media Matters in South Africa. Durban: Media Resource Centre.

Richmond, G. (2008). Cultural pragmatism and The Life of the Sign. Critical Arts, 22(2): 155165.

Rønning, H. (1997). Institutions and Representation. In Zhuwarara, R., Gecau, K. and Drag, M. (eds.) Media, Democratization and Identity. Harare: Department of English, University of Zimbabwe, pp. 1-15. 
Roome, D. (1999). Global versus local: 'Audience-as-public' in South African situation comedy: Suburban Bliss and multicultural female viewers. International Journal of Cultural Studies, 2, 307-328.

Roome, D. (1997). Transformation and reconciliation: 'Simunye' a flexible model. Critical Arts, 11(1/2): 66-94.

Sesanti, S. (2010). The concept of 'respect' in African culture in the context of journalism practice: An Afrocentric intervention. Communicatio, 36(30): 343-358.

Sesanti, S. (2009). Reclaiming space: African women's use of the media as a platform to contest patriarchal representations of African culture - womanists' perspectives. Critical Arts, 23(2): 209-223.

Shepperson, A. (2008). Safety-culture and the Logic of Hazard. Critical Arts: A Journal of South-North Cultural and Media Studies, 22(2): 187-234.

Shepperson, A. and D. Guambe. (1997). Developing Cultural Policy Research Programmes: A Focus on the Material Communities of Cultural Practises. Africa Media Review, 11(1): 18-44.

Shepperson, A. and K.G. Tomaselli. (1999). African Gnoses and Geometries of Difference: 'Science' vs 'Priest-Craft'. In Haines, R. and Wood, G. (eds.)Africa After Modernity: Alternative Perspectives. Port Elizabeth: Institute for Planning and Development Research, University of Port Elizabeth, pp. 47-62.

Sitas, A. (1990). Rethinking Culture? Radical History Review, 46(7): 420-424. Available: http://rhr.dukejournals.org/cgi/pdf_extract/1990/46-47/420

Sitas, A. (1986). Culture and production: The Contradictions of Working Class Theatre in South Africa. Africa Perspective (New Series), 1/2, 84-111.

Smith, L.T. (1999). Decolonizing Methodologies: Research and Indigenous Peoples. Dunedin, New Zealand: University of Otago Press.

Sokal, A.D. (1996). A Physicist Experiments with Cultural Studies, Lingua Franca, May/June, 62-64. Available: http://www.physics.nyu.edu/faculty/sokal/lingua franca v4/lingua franca v4.html

Sokal, A.D. (1995). Transporting the Boundaries: Towards a Transformative Hermeneutics of Quantum Gravity. Social Text, 47/47, 217-252.

Starfield, J. (2002). Change, Continuity and Cultural Studies: The development of an alternative humanities curriculum for Vista University, Soweto. International Journal of Cultural Studies, 5:4, Dec: 405-426. 
Steenveld, L. (2004). Transforming the media: A Cultural Approach. Critical Arts, 18(1): 92115.

Strelitz, L. (2006). Mixed Reception: South African Youth and their Experience of Global media. Pretoria: UNISA Press.

Strelitz, L. and L. Steenveld. (1998). The Fifth Estate: Media theory, watchdog of Journalism. Ecquid Novi, 19(1):100-110.

Switzer, L. (1980). A Critique of the Mass Media at the ASSA Congress. Critical Arts, 1(3): 7075 .

Tager, M. (2010). The Black and the Beautiful: Perceptions of (a) new Generation(s). Critical Arts, 24(1): 99-127.

Tager, M. (1997). Identification and interpretation: The Bold and the Beautiful and the urban black viewer in KwaZulu-Natal. Critical Arts, 11(1/2): 95-119.

Teer-Tomaselli, R.E. (2004).Transforming State Owned Enterprises in the Global Age: Lessons from Broadcasting and Telecommunications in South Africa. Critical Arts, 18(1): 7-41.

Teer-Tomaselli, R.E. (1992). The Politics of Discourse and the discourse of politics: Images of violence and reform in the South African Broadcasting Corporation's Television News bulletins, July 1985 - November 1986. PhD Thesis, University of Natal.

Teer-Tomaselli, R.E. and D. Roome. (eds.) (1997). Identity and popular culture. Critical Arts theme issue, 11(1).

Thompson, E.P. (1968). The Making of the English Working Class. New York: Pantheon Books.

Tomaselli, K.G. (2011). (Afri)Ethics, communitarianism and the public sphere. In Hyde-Clarke, N. (ed.) Communication and Media Ethics in South Africa. Cape Town: Juta.

Tomaselli, K.G. (2000). Ambiguities in Alternative Discourse: New Nation and The Sowetan in the 1980s. In Switzer, L. and Adhikari, M. (eds.) South Africa's Resistance Press: Alternative Voices in the Last Generation Under Apartheid. Athens: Ohio University Press, 378-403.

Tomaselli, K.G. (ed.) (1988). Rethinking Culture. Bellville: Anthropos. (Reprinted in 1989).

Tomaselli, K.G. and CCSU staff and students (1988). Community and the Progressive Press: A Case study in Finding Our Way. Journal of Communication Inquiry, 12(1): 26-44.

Tomaselli, K.G. and C. Chasi. (eds.). (2011). Development and Public Health Communication. Cape Town: Pearson. 
Tomaselli, K.G., S. Gardner, I. Steadman, J. Muller, R.E. Tomaselli, E. Bertelsen, G. Hayman, and D. Maughan Brown. (1983). Retrospective. Critical Arts Monograph No. 2. 22 pp. Reprinted in 1986.

Tomaselli, K.G. and P.E. Louw (eds). (1991a). The Alternative Press in South Africa. London: James Currey (in association with Anthropos, Bellville).

Tomaselli, K.G. and P.E. Louw. (1991b). Disinformation and the South African Defence Force's Theory of War. Social Justice, 18(1/2): 124-140.

Tomaselli, K.G. and A. Shepperson. (2000a). Re-Semiotizing the South African Democratic Project: The African Renaissance. Social Semiotics, 11(1): 91-106.

Tomaselli, K.G. and A. Shepperson. (2000b). South African Cultural Studies: a Journal's Journey from Apartheid to the worlds of the post. In Denzin, N. (ed.) Cultural Studies: A Research Volume 5. Stamford: JAI Press, 3-24.

Tomaselli, K.G. and A. Shepperson. (1999). The Poverty of Journalism: Media Studies and 'Science'. Continuum: Journal of Media and Cultural Studies, 13(2): 237-253.

Tomaselli, K.G. and R.E. Teer-Tomaselli. (2003). New Nation: Anachronistic Catholicism and Liberation Theory. In Curran, J. and Couldry, N. (eds.) Contesting Media Power: Alternative Media in a Networked World. London: Routledge, 195-208.

Tomaselli, K.G., R.E. Tomaselli, P.E. Louw and A.S. Chetty. (1988). Community and Class Struggle: Problems in Methodology. Journal of Communication Inquiry, 12(1): 11-25.

Tomaselli, K.G. and H.K. Wright (eds). (2011). Africa, Cultural Studies and Difference. London: Routledge.

UND (University of Natal, Durban) (1996). African studies project: A working report. Mimeo.

Van Eeden, J. and J. Du Preez. (2005). South African Visual Culture. Pretoria: Van Schaik.

Van Kessel, I. (2000). Beyond our wildest dreams:the United Democratic Front and the transformation of South Africa. London: University Press of Virginia.

Vaughan, M. (1984). A Critique of the dominant Ideas in Departments of English in the Englishspeaking Universities in South Africa. Critical Arts, 3(2): 35-51.

Visser, N. (1984). Introduction: English studies in Transition. Theme issue. Critical Arts, 3(2): 1.

Wasserman, H. and S. Jacobs (eds.) (2003).Shifting selves: Post-apartheid essays on mass media, culture and identity. Cape Town: Kwela Books. 
Webster, F. (2004). Cultural Studies and Sociology at, and after, the closure of the Birmingham School.Cultural Studies, 18(6): 847-863.

Williams, R. (1958). Culture and Society, 1750-1950. London: Chatto \& Windus.

Willoughby, G. (1991). Keyan Tomaselli and the task of cultural criticism. Journal of Literary Studies, 7(1): 64-75.

Windschuttle, K. (1999). Cultural Studies versus Journalism. Quadrant (March):11-20.

Windschuttle, K. (1997). The poverty of media theory. Ecquid Novi, 18(1): 3-20.

Wright, H.K. (2003). Editorial: Whose Diaspora this anyway? Continental Africans trying on and troubling Diasporic identity. Critical Arts, 17(1/2): 1-16. (Theme issue: Africans and the Problematic of Diasporic Identity).

Wright, H.K. (1998). Dare we de-centre Birmingham? Troubling the 'origin' and trajectories of cultural studies. European Journal of Cultural Studies, 1(1):33-50.

Zegeye, A. and M. Vambe. (2009). Close to the Sources. Essays on Contemporary African Culture, Politics and Academy. Pretoria/ New York: University of UNISA Press/ Routledge.

Zhuwarara, R., K. Gecau and M. Drag. (eds). (1997). Media, Democratization and Identity. Harare: Department of English, University of Zimbabwe. 